\title{
Addis Ababa master development plan: A program for development or for ethnic cleansing?*
}

\author{
Aberra Degefa \\ Addis Ababa University \\ P.O. Box 1176, Addis Ababa, Ethiopia \\ (e-mail: kaberra@yahoo.com)
}

\begin{abstract}
It is the legitimate authority of states to prepare and implement development plans. In the democratic society, preparation and implementation of development plans necessarily imply consultations and consent of the local communities affected by the development plan. Such plans should not be unilaterally prepared and coercively imposed on local communities. Any imposed development plan is incompatible with fundamental human rights and freedoms. Thus, the article aims at identifying whether or not the so-called 'Addis Ababa Integrated Master Plan' is a true and elaborate development plan. A real development plan ensures that the intended development project does not result in destruction of the livelihoods and cultural integrity of the local communities living in the project area. The author also considers possible explanations for the Ethiopian Government's refusal to listen to the continuous protests of the Oromo people against the 'Addis Ababa Integrated Master Plan'. In the particular context of regional development aiming at the hidden ethnic cleansing, the intent to destroy a certain group's cultural identity cannot be declared openly by the government but it can be seen in the relevant long-term policies, governmental patterns of actions and facts of everyday life. The article examines from the historical perspective the long-term successive Ethiopian governments' policies and relevant facts to reveal the state's intent to destroy the Oromo identity in Addis Ababa and its suburbs. If the Oromo are evicted from the ancestral land their economic life, social networks, language, cultural traditions and norms will be destroyed, and the Oromo in the area of the 'Addis Ababa Integrated Master Plan' will eventually disappear as a cultural group with a distinct ethnic identity.
\end{abstract}

Key words: regional development plan; Addis Ababa; Oromo; government; protests; human rights; ethnic group; cultural identity

Many states were created by conquest or some kind of violence; many states reconstituted themselves on the basis of people's consent; many former empire-states created by bringing various people together by armed force still exist due to violence. Ethiopia is such an empire-state with no essential changes in the nature of state or the style of governance of its successive rulers. The Ethiopian state was formed and is still maintained by the armed force. In its long history, power has never been transferred from one regime to another peacefully. State institutions have always remained under the hegemony of elites from Amhara or Tigray ethnic groups that are in control of state power and land. Constitutions did not bring any essential changes in the nature of the Ethiopian state institutions and the authoritarian governance. On the contrary,

* C) Defega Aberra, 2019.

The article was submitted on 21.11.2018. 
successive rulers have always refined and strengthened the inherent exclusivist character of state institutions to make them more suitable for their authoritarian governance and predatory purposes $[7 ; 11]$.

The embedded structural violence became a key attitude of the government to the Oromo people from the time of conquest, i.e. Menelik's genocidal war to conquer the Oromo people and control their land. After Menelik's war, the Oromo lost not only sovereignty and land but also their governance system, culture, language and dignity. Various forms of brutal and murderous violence were used by Menelik against the Oromo during the genocidal war of conquest [10]. It is in this structurally phobic historical and political setting for the Oromo that the Government of Ethiopia proposed the 'Addis Ababa Integrated Master Plan' that caused immediate protests of the Oromo. The plan developers consider the Master Plan as a true development project for the benefit of local communities. However, in reality, just similar to the previous Ethiopian rulers' development ideas imposed 'from above', the Government again imposed the Master Plan in the 'top-down' approach. The Master Plan was designed unilaterally by the Government without consultations with the Oromo farmers that will be affected by it for they live in the areas intended for the project. Thus, the article considers possible genocidal impacts of the Master Plan on the Oromo people living in the areas within the territorial borders of the Plan.

The term 'genocide' was used first by the Polish-Jewish jurist Raphael Lemkin in 1944. The term comes from the Greek geno that refers to race or tribe and the Latin word cide that refers to killing. When combined, the term genocide means the destruction of a nation or an ethnic group. Lemkin used the word 'genocide' to refer to violence that destroys a selected group. Such a destruction of an ethnic or national group can be physical, biological, or cultural. Physical genocide aims at annihilation of the group by killing and maiming; biological genocide aims at decreasing the reproductive capacity of the group including policies of separation of sexes and deportation, involuntary sterilization, and undernourishment of parents; cultural genocide aims at weakening and ultimate destruction of cultural values and practices of the group [4].

Lemkin's definition of genocide is broad and holistic and reflects a variety of destructive measures against the group. According to Lemkin, genocide implies a coordinated plan of actions aiming at "the destruction of essential foundations of the life of national groups with the aim of annihilating the groups themselves. The objectives of such a plan would be disintegration of the political and social institutions, of culture, language, national feelings, religion, and the economic existence of national groups, and the destruction of the personal security, liberty, health, dignity, and even the lives of the individuals belonging to such groups. Genocide is directed against the national group as an entity, and the actions involved are directed against individuals, not in their individual capacity, but as members of the national group" [9. P. 147]. In its broader sense, genocide refers to both physical destruction and destruction of the group cultural identity. Genocidal acts do not necessarily imply immediate physical destruction of the group but can be part of the general coordinated plan that aims at the destruction of essential foundations of the life of the national, ethnic, racial or religious group. 
On December 9, 1948, the UN General Assembly unanimously adopted the Convention on the Prevention and Punishment of the Crime of Genocide. Article II of the Convention defines genocide as any of the following acts committed with intent to destroy, in whole or in part, a national, ethnical, racial or religious group, such as killing members of the group; causing serious bodily or mental harm to members of the group; deliberately inflicting on the group conditions of life calculated to bring about its physical destruction in whole or in part; imposing measures intended to prevent births within the group; forcibly transferring children of the group to another group. In the discussions of the draft of the Convention, two definitional approaches - broad and narrow - were developed. The original draft of the Convention submitted for discussion to the Assembly included the destruction of essential foundations of the group's life like political and social institutions, and also culture, language, national feelings, and religion, i.e. cultural genocide. However, a definition narrower than that of Lemkin was included in the final Convention and adopted by the General Assembly. The main reason for adopting the narrower definition was the USA and France's strong opposition to the inclusion of cultural genocide and the Soviet Union's objection to the inclusion of political group [8]. The big powers' desire not to criminalize their own behavior was the main factor that determined the choice of the definition; thus, the narrow definition adopted by the Convention has been criticized for being too restrictive.

Concerning the ways of identifying an intent to destroy as an element of genocide, also two positions were developed in the debates. Some scientists define genocide as an intended action of a certain agent openly willing to cause destruction; other believe that genocide is a structural process that "does not require any intending agent; they more readily recognize genocide as those events that destroy a social collectivity, even if evidence of a coherent intent is not available" [13. P. 19]. According to the Convention, genocide involves one or more acts of the group aiming at destroying another group as a whole or in part. Therefore, regardless of the definition, the object and purpose of the Genocide Convention is to safeguard the very existence of the human groups. The Convention seeks to protect the groups' rights to existence as distinct groups with distinct cultural identities. Thus, the definition given by the Convention implicitly includes cultural destruction/genocide due to mentioning essential characteristics of a group.

Cultural genocide refers to the systematic destruction of culture without killing its representatives. Cultural genocide aims at destruction of the values, culture and the very soul of the national, racial or religious group [19]. In the broad sense, cultural genocide implies attacks that go beyond physical and/or biological elements of the group and seek to destroy its political, social, cultural and language institutions [14]. According to Lemkin, the term 'ethnocide' which is made up of the Greek word ethnos (nation) and the Latin word cide can be used interchangeably with the term 'cultural genocide'. As a rule, the latter has a structural support and takes place over a long period of time as a process and manifests itself in government policies and discriminatory practices [8]. Cultural genocide destroys cultural institutions that provide the group with a sense of holistic communal identity, and destroys people's collectivity by "eroding both their self-esteem and the relationships that bind them together as a community" [19. P. 6]. 
Actually cultural and physical destructions are interrelated, they are interdependent elements of one process taking various forms. Regardless of the form — physical killing or cultural destruction - if the act destroys group characteristics it is genocide [8]. However, cultural genocide aims at the destruction of essential foundations that make up a group without killing its members. Settler colonialism refers to the situation of the direct settlement of colonizing peoples on the territory that they had conquered or subjugated. There is a nexus between genocide and settler colonialism [9;23] for settler colonialism usually has two phases: first, the destruction of the national patterns of the colonized group, then the imposition of the national patterns of the colonizer group provided that the indigenous population was allowed to remain. If the indigenous people are removed from the territory, it is resettled by colonialists and the land is distributed between settlers.

Settler colonialism has some specific features. First, settler colonialists arrive to the land they colonize to stay. They are not migrants who live under the already established political order - they bring their own sovereignty and establish their own political order. Second, settler colonialists' genocide is structural, at aims at the destruction of the indigenous system and creating its own system to ensure the settler group dominance [9]. P. Wolfe [23] also considers settler colonialism as ongoing structural for it destroys the indigenous structure and creates its own colonial rule. That is why G. Tinker [19] defines such long-term systemic violence of settler colonialists as structural genocide.

Today in many developing countries including Africa, governments use terms 'investments' and 'development' to refer to the ongoing extensive land lease/sale although others prefer the term 'land grab'. Regardless of the government's aims, these ongoing land leases lead to the displacement and destruction of livelihoods of million poor farmers. Such displacements and human rights violations gave rise to serious concerns and criticisms from the human rights perspective. Many started to advocate for development 'with human face' and based on the idea of human rights. Even a perfect development plan involving land has the potential of having negative consequences due to the displacement. In order to prevent such negative consequences of development involving displacement, the concerned state is to meet the requirements of free, prior and informed consent of the affected people. To make development human-friendly, those to be affected by the development are to be consulted and participate in the decision-making and benefit-sharing. Whatever reasons or name the government gives to a certain investment or development plan, if it does not imply free, prior and informed consent of the affected people and if it results in the deprivation of group livelihoods and destroyed cultural identity, it is a genocide under the guise of development even of does not affect the groups' physical survival but destroy its livelihoods and culture. Thus, a group can be destroyed by eliminating markers of its culture and identity which leads to the eventual disappearance of the group as a collective entity [16].

In the particular context of development, genocide hides behind the development mask. Besides, one cannot expect today's governments to openly declare the intent to destroy a group for the state will be accused of crime against humanity. In such cases, 
the intent to destroy a group can be seen in the facts of real life serving as indicators of the government plans for genocide. Moreover, from the historical perspective, genocidal acts in the given country can form a sustainable political pattern of persecuting a group and result in the destruction of the group cultural identity [16]. If there is an already established pattern of persecuting a group, this pattern can serve as an indicator of intentional structural genocide. Whatever its aims or grounds are, the group loses livelihoods and identity under the guise of development. The current genocide is proved by the fact that the declared development has the potential to destroy the essential foundations of the groups' life and identity.

Ethiopia was established as a multi-ethnic empire-state at the end of the $19^{\text {th }}$ century by the emperor Menelik. Among the national groups subjugated by Menelik, the largest were the Oromo that lost their land and sovereignty. After winning their genocidal war of conquest, the Abyssinian rulers created state structure and institutions unfriendly to the Oromo values, beliefs, culture and language. The state institutions were made as exclusivist as possible to satisfy the hegemonic ambitions of the rulers. From the very early period, totally ignoring the diversity of the polity, the Abyssinian rulers adopted assimilation policy aiming at making a nation-state out of the multi-ethnic society so as to turn the empire into a prison for nationalities. However, the nationbuilding aspirations of the Ethiopian rulers has always met resistance of the oppressed groups including the Oromo. There were no efforts to change the inherently exclusivist and predatory character of the Ethiopian state machinery and the system as a whole, so the empire never had sustainable peace due to being a tyranny and ethnic hegemony. When we consider the Ethiopian political history, there is one thing that remained despite all changes of regimes and constitutions: whatever Abyssinian group established its hegemonic rule, at first it took political and economic powers and then used the established hegemonic political culture to create and maintain the predatory and exclusivist state institutions.

After losing their land and sovereignty, the Oromo continued to live under the rule of the Abyssinian genocidal state institutions. The inherently genocidal policies of the Ethiopian rulers determined the continuous mistrust between the Oromo and Ethiopian state authorities, and the Oromo has never stopped their struggle for sovereignty and land [6]. Many wonder why the 'Addis Ababa Master Plan' caused such sudden and unprecedented Oromo protests. To understand why the Master Plan caused such protests, one needs a clear understanding of the history of Addis Ababa and of the nature of relationship of the city with the Oromo in general and with those living in its suburbs. Before the foundation of Addis Ababa in 1886, its territory was known as Finfinne and inhabited by different Oromo clans like the Abbichu, Eekka, Galaan and Gullalle belonging to the Tuulama Oromo. Different Oromo clans in the area had their own Gada governance system and leaders, their own beliefs, language and culture [15].

Before the foundation of Addis Ababa there were prosperous Oromo villages and settlements like Birbirsa with the catholic mission. Menelik evicted the Oromo by armed force from their ancestral land and gave this land to his people [1]. The Oromo who lived in and around Finfinnee for generations were evicted by genocidal violence 
in the form of ethnic cleansing. Menelik distributed land between his generals and soldiers to ensure effective control over the Oromo ancestral land. The ruling elites established their own political order and institutions, killed Oromo Gada leaders, christianized Oromo leaders and appointed those who agreed to take Christian name and forget Oromo language, culture and way of life. They changed the names of the places and destroyed the ritual sites of the Oromo people [1;3]. The Oromo song of that time said: No more standing on Inxooxo to look down at the green pasture land below the hill; No more taking cattle to Finfinnee water to water at mineral spring; No more assembly on Tullu Daalatti where the Gullallee tribe meet the assemblage; No more going to Gafarsa to collect firewood; No more taking calves to grazing land on Hurufa bombi; The year the Abyssinians came, our cattle were consumed; With Mashasha's arrival our sovereignty is gone.

After the Oromo were evicted from their ancestral lands, to ensure an effective control over the area Menelik issued the 1907 edict to legalize the Oromo's eviction and to give land titles to his generals and soldiers. It was that edict of Menelik that alienated the indigenous Oromo from their ancestral land. The names of those generals and people with the title Ras were used as the names of different localities (sefers) in Addis Ababa for many years $[1 ; 3 ; 15]$. Thus, Addis Ababa was founded on the Oromo ancestral land after the brutal and genocidal war against the Oromo. The city was established as a settler garrison town repopulated by Menelik's people and the land was distributed among Menelik's army and his people. Since then, Addis Ababa has expanded by displacing and dispossessing more and more Oromo living in its suburbs. Due to these historical facts and the predatory urban policies, the relationship between Addis Ababa and the Oromo living in its suburbs has never been friendly.

In the historical perspective, the politics of successive Ethiopian rulers towards the Oromo has always involved genocide to eradicate the Oromo language, culture and national identity by the assimilation policy. In Addis Ababa, the intent to destroy the Oromo culture and identity can be seen in the legally sanctioned eviction of the Oromo from Addis Ababa and its suburbs during a century $[1 ; 15]$. According to the Oromo, in order to find out whether the 'Addis Ababa Integrated Master Plan' is a true development plan or not, it is important to remember the history of how Addis Ababa was founded and expanded. The city started as a few hectare garrison town on the Oromo land, expanded on the Oromo land and still continues to grow by displacing the indigenous Oromo living in its suburbs [15]. The 'Addis Ababa Integrated Master Plan' aims at integrating the city with the surrounding Oroma towns such as Burayu, Bishoftu, Galan, Sabbata, Sandaafa, Sululta, Laga-Xaafo, Laga-Dhadhi and other semi-urban areas and farmlands. The designers of the Master Plan are aware of the possible negative consequences for the Oromo living in these areas if the Plan is implemented. The designers are also aware of the strong protests against the Plan of wider Oromo public including OPDO officials.

When considering impacts of the Master Plan, one should understand what these areas are meant for according to the Plan: the farmers will be evicted from the farmlands that are the source of their livelihoods and on which they lived for generations. 
The Master Plan does not only grab land but also destroys cultural and linguistic identity of the group. Whatever name is given to the project, it destroys the roots of the Oromo living in these areas and deprives them of their collective identity. Moreover, the Plan was designed in total disregard of the interests of millions of Oromo farmers living in these areas. The Plan is imposed 'from above' as has always been, while a real development plan needs a free and informed consent of the affected people and includes measures to avoid or minimize any possible destruction to local communities. The designers of the Master Plan refuse to recognize examples from other parts of the world concerning legitimate development and ignore Oromo protests of unprecedented scale that has already led to hundreds of innocent victims. Such patterns are clear indicators of the designers' intent to destroy the Oromo identity in the area under the guise of the 'Addis Ababa Integrated Master Plan'. The wider Oromo public believe that the Plan has a double strategy: first, it will legalize the previously illegally annexed Oromo land; then it will create a large territory/region free from the Oromo.

Thus, the history of how Addis Ababa was founded and developed corresponds to what Lemkin [9] and Wolfe [23] wrote about the relationship between settler colonialism and genocide. Addis Ababa's history is a history of genocide including periods of its growth and expansion. If the 'Addis Ababa Integrated Master Plan' results in displacing the Oromo from their ancestral land and in destruction of their cultural identity, then, from the Oromo perspective, the Plan has a genocidal agenda consistent with the previously established government policies.

If we want to understand the aims of the Master Plan and the reasons for the Oromo protests, we should consider the historical power relationship between the Ethiopian state and the Oromo people. Menelik founded Addis Ababa as a garrison town by forcibly taking lands of the Abichu, Eeka, Galan and Gullalle Oromo. The forcible displacement led not only to the total removal of the Oromo but to the destruction of their cultural and identity basis. The city was built, grew and expanded on the graveyard of the Oromo clans that were almost eliminated and replaced by Abyssinian settlers. From its very foundation, the growth and expansion of Addis Ababa has always damaged the livelihoods and identity of the Oromo living in its suburbs, which explains the unprecedented Oromo protests against the unilaterally proposed and imposed 'Addis Ababa Integrated Master Plan”. One needs to assess social-economic, cultural and political impacts of the past development projects on the displaced Oromo who lived in and around Addis Ababa before and after the current government. The Oromo living in the suburbs of Addis Ababa gained nothing except for the loss of livelihoods from the ongoing growth and expansion of Addis Ababa. For the evicted Oromo farmers, the so called 'development' and 'investments' determined only the loss of their ancestral land and their Oromo identity (Oromumma).

If the Master Plan is implemented it will destroy ethnic features of a significant number of the Oromo by evicting them from their ancestral land as their natural, social, economic and cultural environment. For the Oromo as a group, the loss of their ancestral 
land will mean the loss of the essential foundations for preserving their language, culture and identity. What makes the Master Plan genocidal is not the physical destruction of the Oromo as individuals but the destruction of the essential foundations of the Oromo (cultural genocide) which makes it impossible for the Oromo to survive as an ethnic group.

\section{References}

[1] Abba Antonios Albertos. The Apostolic Vicariate of Oromo [Galla], A Capuchin Mission in Ethiopia (1846-1942). Addis Ababa; 1998.

[2] Alamaayyoo Haayilee. Sirna Gadaa Siyaasa Oromoo Tuulama. Finfinnee; 2007.

[3] Benti Getahun. Addis Ababa: Migration and the Making of a Multiethnic Metropolis, 19411974. Asmara; 2007.

[4] Davidson L. Cultural Genocide. New Brunswick; 2012.

[5] Draft Convention on the Crimes of Genocide, UN ESCOR. UN Document E/447(1947).

[6] Eshetu Erena. Ye Oromo taarik kaxint iske 1890 wochu macarasha. Finfinnee; 2009.

[7] Holocomb, Sisay Ibsa. Invention of Ethiopia: The Making of Dependent Colonial State in Northeast Africa. Asmara; 1990.

[8] Kingston L. The destruction of identity: Cultural genocide and indigenous peoples. Journal of Human Rights. 2015; 14.

[9] Lemkin R. Axis Rule in Occupied Europe. Washington; 1944.

[10] Markakis J. Ethiopia. The Last Two Frontiers. Woodbridge; 2011.

[11] Merera Gudina. Ethiopia: From Autocracy to Revolutionary Democracy: 1960s-2011. Addis Ababa; 2011.

[12] Morsink J. Cultural genocide, the Universal Declaration, and minority rights. Human Rights Quarterly. 1999; 21 (4).

[13] Moses A.D. Empire, colony, genocide: Key words and the philosophy of history. Empire, Colony, Genocide, Conquest, Occupation, and Subaltern Resistance in World History. New York; 2009.

[14] Nersessian D. Rethinking cultural genocide under international law, human rights dialogue: Cultural rights. http://www.carnegiecouncil.org/publications/archive/dialogue/2_12/section_ 1/5139.html.

[15] Pankhurst R. State and Land in Ethiopian History. Addis Ababa; 1966.

[16] Roos S.R. Development genocide and ethnocide: Does international law curtail development induced displacement through prohibition of genocide and ethnocide? Center for Human Rights and Humanitarian Law. 2002; 9 (3).

[17] Silina E. Genocide by attrition. International Affairs Working Papers. San Francisco; 2008.

[18] Strauss S. Contested meanings and conflicting imperatives: A conceptual analysis of genocide. Journal of Genocide Research. 2001; 3 (3).

[19] Tinker G.E. Missionary Conquest: The Gospel and Native American Cultural Genocide. Minneapolis; 1993.

[20] Tronvoll K. War and the Politics of Identity in Ethiopia: The Making of Enemies and Allies in the Horn of Africa. New York; 2009.

[21] Vaughan S., Tronvol K. (2003). The Culture of Power in Contemporary Ethiopian Political Life. Sida Studies; 2003.

[22] Veracini L. Settler Colonialism: A Theoretical Overview. London; 2010.

[23] Wolfe P. Settler colonialism and the elimination of the native. Journal of Genocide Research. 2006; 8 (4). 


\title{
Генеральный план развития Аддис-Абебы: программа развития или этнической чистки?*
}

\author{
Аберра Дегефа \\ Университет Аддис-Абебы \\ А/я 1176, Аддис-Абеба, Эфиопия \\ (e-mail: kaberra@yahoo.com)
}

Власти любой страны имеют легитимное право разрабатывать и реализовывать планы регионального развития. В демократических обществах разработка подобных планов и тем более их практическая реализация с необходимостью предполагают консультации с местными сообществами и получение согласия тех групп, жизнь которых подвергнется неизбежным изменениям. Подобные планы не должны разрабатываться в одностороннем порядке и насильно навязываться местным сообществам. Их принуждение к участию в реализации планов развития противоречит фундаментальным правам и свободам человека. Статья призвана ответить на вопрос, можно ли считать так называемый «Объединенный генеральный план развития Аддис-Абебы» планом развития: любой настоящий проработанный план развития предполагает, что задуманный проект не приведет к лишению местных сообществ средств к существованию или к разрушению культурного единства групп, проживающих на данной территории. Автор также выдвигает возможные объяснения нежеланию правительства Эфиопии прислушаться к продолжающимся протестам народности оромо против «Объединенного генерального плана развития Аддис-Абебы». В конкретном контексте регионального развития, тайно нацеленного на этническую чистку, правительство не может открыто декларировать намерение уничтожить культурную идентичность определенной группы, но таковое можно обнаружить в соответствующих долгосрочных политических мерах, предпочитаемых правительством стратегиях и фактах действительности. В статье с исторической точки зрения рассмотрена долгосрочная последовательная политика правительства Эфиопии и факты, позволяющие утверждать наличие у государства стремления уничтожить идентичность народности оромо в Аддис-Абебе и ее пригородах. Если оромо выселят с территорий их предков, их экономическая жизнь, социальные сети, язык, культурные традиции и нормы будут утрачены и, согласно «Объединенному генеральному плану развития Аддис-Абебы», оромо как культурная группа с особой этнической идентичностью исчезнет из районов, где этот план будет реализован.

Ключевые слова: региональный план развития; Аддис-Абеба; народность оромо; правительство; протесты; права человека; этническая группа; культурная идентичность

* (C) Аберра Дегефа, 2019.

Статья поступила в редакиџию 21.11.2018. 